\title{
Update in Endocrine Pathology
}

\author{
Özgür METE ${ }^{1,2,3}$ \\ 'Department of Pathology, University Health Network, TORONTO, ONTARIO, CANADA, \\ ${ }^{2}$ Department of Laboratory Medicine and Pathobiology, University of Toronto, ONTARIO, CANADA \\ ${ }^{3}$ Endocrine Oncology Site Group, Princess Margaret Cancer Centre, TORONTO, ONTARIO, CANADA
}

\section{UPDATE IN ENDOCRINE PATHOLOGY}

Over the past decades, endocrine pathology has emerged as a distinct clinical subspecialty in the field of surgical pathology. Endocrine pathologists play an essential role in the management of patients with endocrine disorders arising from pineal, hypothalamus, pituitary, parathyroid, thyroid, adrenal, paraganglia, pancreas, gastrointestinal tract, lung, thymus, and urogenital system. Recent advancements made in translational endocrine research utilizing molecular testing has significantly improved our understanding of the pathogenesis of endocrine neoplasms and simultaneously led to the development of modern practices that integrate diagnostic, predictive, and prognostic biomarkers. In this special issue of the Turkish Journal of Pathology, several experts have been invited to provide an update on the expanding knowledge of endocrine disorders.

Pituitary adenomas are common neuroendocrine tumors, found in approximately $20 \%$ of the general population (1-3). The diagnosis of pituitary adenoma alone or demonstration of hormone products in a pituitary adenoma is no longer sufficient for the management of these patients. Accurate subtyping of pituitary adenomas in conjunction with some biomarkers is crucial (1-4). The distinct behaviour of a select group of pituitary adenomas in specific clinical settings is discussed by Mete and coworkers.

Pathologists are often faced with the question of how to distinguish a malignancy during the preoperative assessment of thyroid nodules. The overall rate of malignancy in thyroid nodules is as high as $15 \%(5-6)$. In this special issue, challenges and pitfalls associated with the cytological evaluation of thyroid nodules are discussed by Schmitt and coworkers.

Papillary thyroid carcinoma is the most common endocrine malignancy. Several variants of papillary thyroid carcinoma have been described based on the size, architecture, cytology, nature of the tumor boundaries, stromal features,

(Turk Patoloji Derg 2015, 31(Suppl):1-3) additional components, or a combination of these features (7-9). In this special issue, the histopathologic and clinical features of common histological variants of papillary thyroid carcinoma are summarized by Serpil Dizbay Sak.

The distinction of dedifferentiation is of clinical significance. While the diagnosis of anaplastic (undifferentiated) thyroid carcinoma is generally made after excluding other undifferentiated malignant neoplasms using immunohistochemical tools, the diagnosis of poorly differentiated thyroid carcinoma is often rendered morphologically $(7,10,11)$. Recent advances in our understanding of the histologic, imunohistochemical, and molecular characteristics of poorly differentiated and anaplastic thyroid carcinoma are summarized by SobrinhoSimões and coworkers.

Medullary thyroid carcinoma originates from parafollicular C-cells and represents fewer than $10 \%$ of all thyroid cancers (12-14). In this special issue, the morphological and molecular features of C-cell disease are discussed by Baloch and LiVolsi by reviewing diagnostic pitfalls as well as the latest American Thyroid Association guidelines for management of patients with medullary thyroid carcinoma (15).

Clinicopathological correlates of primary hyperparathyroidism include parathyroid adenoma (80-85\%), hyperplasia (10-15\%) and carcinoma (<1-5\%) (16). Advances in molecular pathology have shed light to the pathogenesis of parathyroid neoplasms and resulted in the development of new biomarkers $(17,18)$. The review submitted by Duan and Mete provides an update on the current knowledge of parathyroid carcinoma by highlighting diagnostic pitfalls as well as its exciting changes in the practice of endocrine oncology.

Adrenal cortical carcinoma is now recognized as a heterogeneous disease with various molecular background and prognostic features unmatched with morphological features in most cases $(9,19-21)$. The reticulin algorithm
Correspondence: Özgür METE

200 Elizabeth Street, 11th Floor, Department of Pathology,

University Health Network, M4Y 3G5, TORONTO, ON, CANADA

E-mail: ozgur.mete2@uhn.ca Phone: +1 4163403004 
introduced by Volante and colleagues provided a simplified and reliable approach to distinguish malignancy $(22,23)$. Transcriptome studies of adrenal cortical carcinomas showed that the diagnosis of malignancy can be rendered by using molecular techniques. Moreover, they also highlighted two distinct molecular subgroups depending on the behavior of adrenal cortical carcinoma ("poor" versus "improved" survival outcome) $(19,20)$. The various aspects of adrenal cortical carcinoma are discussed by Papotti and coworkers.

The last decade has provided significant progress in the field of neuroendocrine disease. The discoveries of genetic susceptibility in up to $40 \%$ of paraganglioma and pheochromocytoma led to the development of genotypephenotype correlations as well as standardized synoptic reporting to advance the medical care (24-28). In this special issue, advances in paraganglioma and pheochromocytoma are reviewed by Alfred Lam.

The nomenclature for gastro-entero-pancreatic (GEP) neuroendocrine tumors (NETs) has been an area of controversy in medicine. Many terms have been applied to what we now call as neuroendocrine tumor or neuroendocrine carcinoma. The 2010 WHO classification of GEP-NETs introduced a histologic grading system based on the proliferation rate (mitotic count and Ki67 labeling index) (29). On the other hand, the $7^{\text {th }}$ edition of the AJCC/ UICC staging scheme provided for the first time a site specific and grade dependant staging for GEP-NETs. While the field of GEP-NETs is still evolving to optimize diagnosis and management, the colorful aspect of GEP-NETs are discussed by La Rosa and coworkers.

The morphologic, immunohistochemical, and molecular features of neuroendocrine tumors of the gynecological tract along with other endocrine tumors in the gynecological tract are discussed in the review submitted by Kefeli and Usubutun.

The manifestations of endocrine disorders may also present with dermatological diseases. As a consequence, awareness of the skin manifestations of endocrine disorders alert physicians to further initiate a comprehensive endocrine workup. A brief review of skin lesions associated with endocrine disorders is summarized by Cuyan Demirkesen.

In addition to paraneoplastic syndromes leading to clinical or biochemical endocrine disorders, growing evidence expanded the link between inherited endocrine tumour syndromes (30-32) and genitourinary disorders. The review submitted by Özlük and Kılıçaslan discusses comprehensive aspects of this association.
Over the past few years, important milestones in the understanding of metabolic syndrome and type 2 diabetes mellitus have been achieved (33-35). Chronic low grade inflammation in adipose tissue is now known to play a key role in obesity and insulin resistance. As a result, adipose tissue is currently recognized as an active immune organ regulating energy metabolism. Winer and coworkers summarized the expanding knowledge on the pathology of innate and adaptive immune cells in obese adipose tissue by emphasising various immunological mechanisms leading to obesity-related insulin resistance.

Progress in the cellular and molecular biology led to increased usage of molecular biologic techniques in modern practices. The review article submitted by Serinsoz Linke and Guler Tezel summarizes an update of genetic changes observed in different endocrine system pathologies and their diagnostic, therapeutic and prognostic values.

As the field of endocrine pathology continues to evolve on a daily basis, the authors of this special issue provided timely updates for diagnostic pathologists and treating physicians in multidisciplinary endocrine oncology teams.

\section{REFERENCES}

1. Mete O, Asa SL. Clinicopathological correlations in pituitary adenomas. Brain Pathol. 2012;22:443-53.

2. Asa SL. Tumors of the pituitary gland. Washington, DC: Armed Forces Institute of Pathology; 2011.

3. Mete O, Asa SL. Therapeutic implications of accurate classification of pituitary adenomas. Semin Diagn Pathol. 2013;30:158-64.

4. Mete O, Ezzat S, Asa SL. Biomarkers of aggressive pituitary adenomas. J Mol Endocrinol. 2012;49:R69-78.

5. American Thyroid Association (ATA) Guidelines Taskforce on Thyroid Nodules and Differentiated Thyroid Cancer, Cooper DS, Doherty GM, Haugen BR, Kloos RT, Lee SL, Mandel SJ, Mazzaferri EL, McIver B, Pacini F, Schlumberger M, Sherman SI, Steward DL, Tuttle RM. Revised American Thyroid Association management guidelines for patients with thyroid nodules and differentiated thyroid cancer. Thyroid. 2009;19:1167-214.

6. Chaikhoutdinov I, Mitzner R, Goldenberg D. Incidental Thyroid Nodules: Incidence, Evaluation, and Outcome. Otolaryngol Head Neck Surg. 2014; 150:939-942.

7. DeLellis RA, Lloyd RV, Heitz PU, Eng C, eds. World Health Organization Classification of Tumours. Pathology and Genetics of Tumours of Endocrine Organs. Lyon: IARC Press, 2004.

8. Baloch Z, LiVolsi VA, Tondon R. Aggressive variants of follicular cell derived thyroid carcinoma; the so called 'real thyroid carcinomas'. J Clin Pathol. 2013;66:733-43.

9. Mete O, Asa SL, eds. Endocrine Pathology. Cambridge University Press; 2016. 
10. Gnemmi V, Renaud F, Do Cao C, Salleron J, Lion G, Wemeau JL, Copin MC, Carnaille B, Leteurtre E, Pattou F, Aubert S. Poorly differentiated thyroid carcinomas: Application of the Turin proposal provides prognostic results similar to those from the assessment of high-grade features. Histopathology. 2014;64:26373 .

11. Volante M, Collini P, Nikiforov YE, Sakamoto A, Kakudo K, Katoh R, Lloyd RV, LiVolsi VA, Papotti M, Sobrinho-Simoes M, Bussolati G, Rosai J. Poorly differentiated thyroid carcinoma: The Turin proposal for the use of uniform diagnostic criteria and an algorithmic diagnostic approach. Am J Surg Pathol. 2007;31:125664.

12. Albores-Saavedra J, LiVolsi VA, Williams ED. Medullary carcinoma. Seminars in Diagnostic Pathology. 1985; 2:137-146

13. Wells SA, Jr., Franz C. Medullary carcinoma of the thyroid gland. World J Surg. 2000; 24:952-956

14. Matias-Guiu X, De Lellis R. Medullary thyroid carcinoma: A 25year perspective. Endocr Pathol. 2014; 25:21-29

15. Wells SA Jr, Asa SL, Dralle H, Elisei R, Evans DB, Gagel RF, Lee N, Machens A, Moley JF, Pacini F, Raue F, Frank-Raue K, Robinson B, Rosenthal MS, Santoro M, Schlumberger M, Shah M, Waguespack SG. Revised american thyroid association guidelines for the management of medullary thyroid carcinoma. Thyroid. 2015;25:567-610.

16. Duan K, Gomez-Hernandez K, Mete O. Clinicopathological correlates of hyperparathyroidism. J Clin Pathol. 2015, in press.

17. Gill AJ. Understanding the genetic basis of parathyroid carcinoma. Endocr Pathol. 2014;25:30-4.

18. Erovic BM, Harris L, Jamali M, Goldstein DP, Irish JC, Asa SL, Mete O. Biomarkers of parathyroid carcinoma. Endocr Pathol. 2012;23:221-31.

19. Giordano TJ, Kuick R, Else T, Gauger PG, Vinco M, Bauersfeld J, Sanders D, Thomas DG, Doherty G, Hammer G. Molecular classification and prognostication of adrenocortical tumors by transcriptome profiling. Clin Cancer Res. 2009;15:668-76.

20. Ragazzon B, Assié G, Bertherat J. Transcriptome analysis of adrenocortical cancers: From molecular classification to the identification of new treatments. Endocr Relat Cancer. 2011;18:R15-27.

21. Papotti M, Duregon E, Volante M, McNicol AM. Pathology of the adrenal cortex: A reappraisal of the past 25 years focusing on adrenal cortical tumors. Endocr Pathol. 2014;25:35-48.

22. Volante M, Bollito E, Sperone P, Tavaglione V, Daffara F, Porpiglia F, Terzolo M, Berruti A, Papotti M. Clinicopathological study of a series of 92 adrenocortical carcinomas: From a proposal of simplified diagnostic algorithm to prognostic stratification. Histopathology. 2009;55:535-43.

23. Duregon E, Fassina A, Volante M, Nesi G, Santi R, Gatti G, Cappellesso R, Dalino Ciaramella P, Ventura L, Gambacorta M, Dei Tos AP, Loli P, Mannelli M, Mantero F, Berruti A, Terzolo M, Papotti M. The reticulin algorithm for adrenocortical tumor diagnosis: A multicentric validation study on 245 unpublished cases. Am J Surg Pathol. 2013;37:1433-40.
24. Mete O, Tischler AS, de Krijger R, McNicol AM, Eisenhofer G, Pacak K, Ezzat S, Asa SL. Protocol for the examination of specimens from patients with pheochromocytomas and extraadrenal paragangliomas. Arch Pathol Lab Med. 2014;138:182-8.

25. Tischler AS, Pacak K, Eisenhofer G. The adrenal medulla and extra-adrenal paraganglia: Then and now. Endocr Pathol. 2014 Mar;25(1):49-58.

26. Flynn A, Benn D, Clifton-Bligh R, Robinson B, Trainer AH, James P, Hogg A, Waldeck K, George J, Li J, Fox SB, Gill AJ, McArthur G, Hicks RJ, Tothill RW. The genomic landscape of phaeochromocytoma. J Pathol. 2015;236:78-89.

27. King KS, Pacak K. Familial pheochromocytomas and paragangliomas. Mol Cell Endocrinol. 2014;386:92-100.

28. Mete O, Tischler A, de Krijger R, McNicol AM, Giordano T, Ezzat $\mathrm{S}$, Asa SL. The clinical role of pathologists in the management of patients with paragangliomas and pheochromocytomas. Journal of Clinical Endocrinology and Metabolism, 2014, October 9, online. Available at: http://press.endocrine.org/e-letters/10.1210/ jc.2014-1498.

29. Bosman FT, Carneiro F, Hruban RH, Theise ND (Eds.) WHO Classification of Tumors of the Digestive System. IARC: Lyon, 2010

30. Gill AJ, Hes O, Papathomas T, Šedivcová M, Tan PH, Agaimy A, Andresen PA, Kedziora A, Clarkson A, Toon CW, Sioson L, Watson N, Chou A, Paik J, Clifton-Bligh RJ, Robinson BG, Benn DE, Hills K, Maclean F, Niemeijer ND, Vlatkovic L, Hartmann A, Corssmit EP, van Leenders GJ, Przybycin C, McKenney JK, Magi-Galluzzi C, Yilmaz A, Yu D, Nicoll KD, Yong JL, Sibony M, Yakirevich E, Fleming S, Chow CW, Miettinen M, Michal M, Trpkov K. Succinate dehydrogenase (SDH)-deficient renal carcinoma: A morphologically distinct entity: A clinicopathologic series of 36 tumors from 27 patients. Am J Surg Pathol. 2014;38:1588-602.

31. Hernandez KG, Ezzat S, Morel CF, Swallow C, Otremba M, Dickson BC, Asa SL, Mete O. Familial pheochromocytoma and renal cell carcinoma syndrome: TMEM127 as a novel candidate gene for the association. Virchows Arch. 2015;466:727-32.

32. Cassol C, Mete O. Endocrine manifestations of von HippelLindau disease. Arch Pathol Lab Med. 2015;139:263-8.

33. Winer DA, Winer S, Shen L, Wadia PP, Yantha J, Paltser G, Tsui $\mathrm{H}$, Wu P, Davidson MG, Alonso MN, Leong HX, Glassford A, Caimol M, Kenkel JA, Tedder TF, McLaughlin T, Miklos DB, Dosch HM, Engleman EG. B cells promote insulin resistance through modulation of $\mathrm{T}$ cells and production of pathogenic IgG antibodies. Nat Med. 2011;17:610-7.

34. Revelo XS, Luck H, Winer S, Winer DA. Morphological and inflammatory changes in visceral adipose tissue during obesity. Endocr Pathol. 2014;25:93-101.

35. Tsai S, Clemente-Casares X, Revelo XS, Winer S, Winer DA. Are obesity-related insulin resistance and type 2 diabetes autoimmune diseases? Diabetes. 2015;64:1886-97. 